\title{
Women and Children Health Status of Nomadic People of Changthang Ladakh
}

\author{
Tashi Dolkar*, Sabiya Asmat, Anupa Sharma, Feroz Din Sheikh and Hummara Azim
}

Krishi Vigyan Kendra, Kargil II and I, S. K University of Agriculture Science and Technology of Kashmir, Srinagar, Jammu and Kashmir, India

Department of Social Welfare, Kashmir University, Jammu, Jammu and Kashmir, India

*Corresponding author

\section{A B S T R A C T}

\section{Keywords}

Changpa, Nomads, Women, Children, Health Households

Article Info

Accepted:

18 March 2021

Available Online:

10 April 2021
The present study was aimed at people of Changthang, known as Changpa, who are nomadic shepherds. The Changpa nomads lived in rebo (tents) made from yak wool. The data reveal that all changpa nomads used bukhari for their heating purpose. They used wood and cow dung cake as fuel in bukhari and majority $82.86 \%$ of both women and children go to primary health centre because PHC also keeps moving with their camps so they prefer to go to PHC, only $5.57 \%$ of respondents went to district hospital when they are seriously sick.

\section{Introduction}

The people of the Changtang are nomadic pastoralists, they are known as 'Changpa', for 'northerners,' or 'Drukpa' for 'nomads' in Tibetan. The people are divided into two sections. One is called Rongpa (Yulpa)-that is to say, 'dwellers in villages,' and the other, the Changpa, meaning 'dwellers in the desert'. The Changpas are a nomadic pastoral community who rare animals they move from place to place across the Changthang, staying in yak wool tents (rebos). The people of Changthang, the Changpas are of Tibetan race are not different from other Ladakhis in their customs and religion. The Changpas speak Changkyet/Chanskat, a Tibetan dialect (Bhasin, 201 2). The culture of Changthangi people is an interesting mix of Tibetan and other customs. The Changpa are Buddhists and share cultural and linguistic affinities with Tibet (Rizvi, 1996).

Changpa nomads weave cloth from wool acquired from Yak and goats which has been a traditional occupation. Raising livestock seems to have been main occupations providing clothing, shelter, and food. Having cheerfully adapted to the harsh weather and austere living conditions. 
(www.indianetzone.com Tribes of Jammu and Kashmir). The staple diet of region is huskless barley, or grim, which is roasted and ground for use as flour, tsampa (Tibetan) or namphey (Ladakhi), or for making the local beer brew, chhang. For a quick, nutritious and warming breakfast or lunch it is hard to beat butter tea with kholak. These foods are easy to make, simple, least fuel consuming, ingredients available locally and preferred. The majority of the dishes that follows are sustaining food for the people of a remote region.

In Ladakh women actively take part in all agricultural activities. Especially, in recent times, one of the significant features of the unique, mountainous region of Ladakh, lying on the high altitude has been the transformation in the traditional subsistence economy and trends towards livelihood diversification among the genders. The livelihood diversification has direct impact on the dominant economic activities of the region.

The pastoral and agriculture activities have been entirely dependent on each other and the it is subsistence type and only a few crops have been traditionally grown, because of cold arid climate, high altitude, extremely rugged and isolated terrain, absence of market etc.

Crops which are grown in majority comprised of Grim (Naked Barley), wheat, peas and alfaalfa; and crop protection activities activities are mostly performed following organic organic concepts (Dar et al., 2014; Dar et al., 2020 a, b; Dar et al., 2021a, b, c; Tlak Gajger and Dar, 2021).

The nomads of Changthang pastoral production system is a multiple output system, with outcomes like milk, meat, wool, skin, dung etc. The nomads harvested the livestock products for their own consumption and for sale to the market. In addition, the nomads bought food rations and other items from the market (Bagchi, et al., 2004) The main occupation of the Changpa community is animal husbandry. Geographically situated in the eastern part of Ladakh. The land of nomads located in the east of Leh on the Chinese border.

\section{Materials and Methods}

The sample for the study was drawn from Nyoma block of Changthang region. Nyoma block consists of 18 villages from which 7 villages were selected for the study, namely, Hanley, Koyul, Korzok, Samad, Kharnak, Angkung and Sumdo. From Hanley, Karzok and Samad 40 households were selected and 15 households were selected from Karnak, Ankung and Sumdo. From Koyul 25 households were selected for the study totalling to 190 families (household) in the study area. From each household only women were selected. The primary data was collected through participant observation, selfstructured interview schedule, was also be used for collecting the desired information. The secondary data was collected from the published reports, magazines etc, and from various official sources.

\section{Results and Discussion}

\section{Basic Essential Facilities}

The data presented in Table 1 reveals that from all the seven villages all the $100 \%$ of respondents (i.e. women and children of Changpa nomads) were staying in yak wool tents (rebo) which were made from traditionally yak wool. All the respondents noted that they stayed comfortably in rebo (tent). Table no 2 reveals that $100 \%$ of changpa nomads used bukhari for their heating purpose.They used wood and cow dung cake as fuel in bukhari. Bukhari was used for dual purpose i:e cooking and heating the room 
Table.1 Type of house

\begin{tabular}{|c|c|c|c|c|c|c|c|c|c|c|c|c|c|c|c|c|}
\hline \multirow[b]{2}{*}{ House } & \multicolumn{2}{|c|}{ Koyul } & \multicolumn{2}{|c|}{ Korzok } & \multicolumn{2}{|c|}{ Sumdo } & \multicolumn{2}{|c|}{ Kharnak } & \multicolumn{2}{|c|}{ Angkung } & \multicolumn{2}{|c|}{ Samad } & \multicolumn{2}{|c|}{ Hanlay } & \multicolumn{2}{|c|}{ Overall Total } \\
\hline & $\begin{array}{l}n= \\
61\end{array}$ & $\%$ & $\begin{array}{c}n=1 \\
16\end{array}$ & $\%$ & $\begin{array}{l}n= \\
37\end{array}$ & $\%$ & $\begin{array}{c}n \\
=48\end{array}$ & $\%$ & $\begin{array}{l}n= \\
39\end{array}$ & $\%$ & $\begin{array}{c}n=1 \\
05\end{array}$ & $\%$ & $\begin{array}{c}n=9 \\
6\end{array}$ & $\%$ & $\begin{array}{c}\mathrm{n}=\mathbf{5 0} \\
\mathbf{2}\end{array}$ & $\%$ \\
\hline $\begin{array}{c}\text { Kaccha } \\
\text { (mud } \\
\text { house) }\end{array}$ & - & & - & & - & & - & & - & & - & & - & & - & - \\
\hline $\begin{array}{c}\text { Tent } \\
\text { (rebo) }\end{array}$ & 61 & 100 & 116 & 100 & 37 & 100 & 48 & 100 & 39 & 100 & 105 & 100 & 96 & 100 & 502 & 100 \\
\hline $\begin{array}{c}\text { Semi } \\
\text { Kaccha }\end{array}$ & - & & - & & & & & & & & & - & & & & \\
\hline Total & 61 & 100 & 116 & 100 & 37 & 100 & 48 & 100 & 39 & 100 & 105 & 100 & 96 & 100 & 502 & 100 \\
\hline & & & & & Feel & omfo & table & tayin & in 1 & bo $(\mathrm{T}$ & nt) & & & & & \\
\hline Yes & 61 & 100 & 116 & 100 & 37 & 100 & 48 & 100 & 39 & 100 & 105 & 100 & 96 & 100 & 502 & 100 \\
\hline No & - & - & - & & 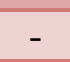 & &  & & - & &  & & - & & - & - \\
\hline Total & 61 & 100 & 116 & 100 & 37 & 100 & 48 & 100 & 39 & 100 & 105 & 100 & 96 & 100 & 502 & 100 \\
\hline
\end{tabular}

Table.2

\begin{tabular}{|c|c|c|c|c|c|c|c|c|c|c|c|c|c|c|}
\hline \multirow{2}{*}{$\begin{array}{l}\text { What is the } \\
\text { source for } \\
\text { heating } \\
\text { purpose }\end{array}$} & \multicolumn{2}{|c|}{ Village 1} & \multicolumn{2}{|c|}{ Village 2} & \multicolumn{2}{|c|}{ Village 3} & \multicolumn{2}{|c|}{ Village 4} & \multicolumn{2}{|c|}{ Village5 } & \multicolumn{2}{|c|}{ Village6 } & \multicolumn{2}{|c|}{ Village7 } \\
\hline & No & $\%$ & No & $\%$ & No & $\%$ & No & $\%$ & No & $\%$ & No & $\%$ & No & $\%$ \\
\hline Bukhari & 31 & 100 & 58 & 100 & 19 & 100 & 29 & 100 & 23 & 100 & 62 & 100 & 56 & 100 \\
\hline Heat $k$ & - & - & - & - & - & - & - & - & - & - & - & - & - & - \\
\hline Other & - & - & - & - & - & - & - & - & - & - & - & - & - & - \\
\hline Total & 31 & 100 & 58 & 100 & 19 & 100 & 29 & 100 & 23 & 100 & 62 & 100 & 56 & 100 \\
\hline
\end{tabular}

Table.3 General health problems of the women and children due to migration

\begin{tabular}{|c|c|c|c|c|c|c|c|c|c|c|c|c|c|c|c|}
\hline \multirow{2}{*}{$\begin{array}{l}\text { Health } \\
\text { problem of } \\
\text { the } \\
\text { respondents }\end{array}$} & \multicolumn{2}{|c|}{ Koyul } & \multicolumn{2}{|c|}{ Korzok } & \multicolumn{2}{|c|}{ Sumdo } & \multicolumn{2}{|c|}{ Kharnak } & \multicolumn{2}{|c|}{ Angkung } & \multicolumn{2}{|c|}{ Samad } & \multicolumn{2}{|c|}{ Hanlay } & $\begin{array}{c}\text { Overall } \\
\text { Total }\end{array}$ \\
\hline & $\mathrm{n}=61$ & $\%$ & $n=116$ & $\%$ & $\mathrm{n}=\mathbf{3 7}$ & $\%$ & $n=48$ & $\%$ & $n=39$ & $\%$ & $n=105$ & $\%$ & $n=96$ & $\%$ & $\mathrm{n}=502 \quad \%$ \\
\hline $\begin{array}{l}\text { General } \\
\text { diseases }\end{array}$ & 61 & 100 & 11 & 100 & 37 & 100 & 48 & 100 & 39 & 100 & 105 & 100 & 96 & 100 & 502(100) \\
\hline $\begin{array}{l}\text { Serious } \\
\text { diseases }\end{array}$ & - & - & - & - & - & - & - & - & - & - & - & - & - & - & - \\
\hline $\begin{array}{l}\text { Infectious } \\
\text { diseases }\end{array}$ & - & & - & - & - & & & 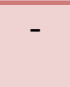 & - & - & - & & - & - & - \\
\hline Total & 61 & 100 & 116 & 100 & 37 & 100 & 48 & 100 & 39 & 100 & 105 & 100 & 96 & 100 & $502(100)$ \\
\hline
\end{tabular}


Table.4 Impact of Women's health on her family

\begin{tabular}{|c|c|c|c|c|c|c|c|c|c|c|c|c|c|c|c|}
\hline \multirow{2}{*}{$\begin{array}{l}\text { Responde } \\
\text { nts }\end{array}$} & \multicolumn{2}{|c|}{ Koyul } & \multicolumn{2}{|c|}{ Korzok } & \multicolumn{2}{|c|}{ Sumdo } & \multicolumn{2}{|c|}{ Kharnak } & \multicolumn{2}{|c|}{ Angkung } & \multicolumn{2}{|c|}{ Samad } & \multicolumn{2}{|c|}{ Hanlay } & \multirow{2}{*}{$\begin{array}{c}\begin{array}{c}\text { Overall } \\
\text { Total }\end{array} \\
\mathbf{n}=278 \\
\end{array}$} \\
\hline & $\begin{array}{l}n= \\
31\end{array}$ & $\%$ & $\begin{array}{l}n= \\
58\end{array}$ & $\%$ & $\begin{array}{l}n= \\
19\end{array}$ & $\%$ & $\begin{array}{l}n= \\
29\end{array}$ & $\%$ & $\begin{array}{l}n= \\
23\end{array}$ & $\%$ & $\begin{array}{l}n= \\
62\end{array}$ & $\%$ & $\begin{array}{c}n=5 \\
6\end{array}$ & $\%$ & \\
\hline $\begin{array}{c}\text { Can } \\
\text { perform } \\
\text { household } \\
\text { chore }\end{array}$ & - & - & - & - & - & - & - & - & - & - & - & - & - & - & - \\
\hline $\begin{array}{c}\text { Take care } \\
\text { of } \\
\text { children }\end{array}$ & - & - & - & - & - & - & - & - & - & - & - & - & - & - & - \\
\hline $\begin{array}{c}\text { Care of } \\
\text { other } \\
\text { family } \\
\text { member }\end{array}$ & 11 & 35.48 & - & - & - & - & - & - & 6 & 26.08 & 10 & 16.12 & - & - & $27(9.71)$ \\
\hline $\begin{array}{c}\text { For her } \\
\text { own } \\
\text { health }\end{array}$ & 20 & 64.51 & 58 & 100 & 19 & 100 & 29 & 100 & 17 & 73.91 & 52 & 83.87 & 56 & 100 & $251(90.28)$ \\
\hline No effect & - & - & - & - & - & - & - & - & - & - & - & - & - & - & - \\
\hline Total & 20 & 64.51 & 58 & 100 & 19 & 100 & 29 & 100 & 17 & 73.91 & 52 & 83.87 & 56 & 100 & $251(90.28)$ \\
\hline
\end{tabular}

Table.5 Knowledge about balanced diet (children and women)

\begin{tabular}{|c|c|c|c|c|c|c|c|c|c|c|c|c|c|c|c|}
\hline \multirow[t]{2}{*}{ Responses } & \multicolumn{2}{|c|}{ Koyul } & \multicolumn{2}{|c|}{ Korzok } & \multicolumn{2}{|c|}{ Sumdo } & \multicolumn{2}{|c|}{ Kharnak } & \multicolumn{2}{|c|}{ Angkung } & \multicolumn{2}{|c|}{ Samad } & \multicolumn{2}{|c|}{ Hanlay } & $\begin{array}{c}\text { Overall } \\
\text { Total }\end{array}$ \\
\hline & $\mathrm{n}=61$ & $\%$ & $\mathrm{n}=116$ & $\%$ & $\mathrm{n}=37$ & $\%$ & $\mathrm{n}=48$ & $\%$ & $\mathrm{n}=39$ & $\%$ & $\mathrm{n}=105$ & $\%$ & $\mathrm{n}=96$ & $\%$ & $\mathrm{n}=502 \quad \%$ \\
\hline Yes & 4 & 6.55 & 6 & 5.17 & - & - & - & - & 3 & 7.69 & 3 & 2.85 & 9 & 9.37 & $25(4.98)$ \\
\hline No & 57 & 93.44 & 110 & 94.82 & 37 & 100 & 48 & 100 & 36 & 92.30 & 102 & 97.14 & 87 & 90.62 & $477(95.01)$ \\
\hline Total & 61 & 100 & 116 & 100 & 37 & 100 & 48 & 100 & 39 & 100 & 105 & 100 & 96 & 100 & $502(100)$ \\
\hline \multicolumn{16}{|c|}{ Source of information } \\
\hline Radio & 2 & 3.27 & 4 & 3.44 & - & - & - & - & 3 & 7.69 & 3 & 2.85 & 9 & 9.37 & $21(4.1)$ \\
\hline TV & - & - & - & - & - & - & - & - & - & - & - & - & - & - & - \\
\hline PHC & - & - & - & - & - & - & - & - & - & - & - & - & - & - & - \\
\hline Anganwadi & 2 & 3.27 & 2 & 1.72 & - & - & - & - & - & - & - & - & - & - & $4(0.79)$ \\
\hline $\begin{array}{l}\text { Family } \\
\text { member }\end{array}$ & - & - & - & - & - & - & - & - & - & - & - & - & - & - & - \\
\hline None & - & - & - & - & - & - & - & - & - & - & - & - & - & - & - \\
\hline Total & 4 & 6.55 & 6 & 5.17 & - & - & - & - & 3 & 7.69 & 3 & 2.85 & 9 & 9.37 & $25(4.98)$ \\
\hline
\end{tabular}


Fig.1 Place of treatment

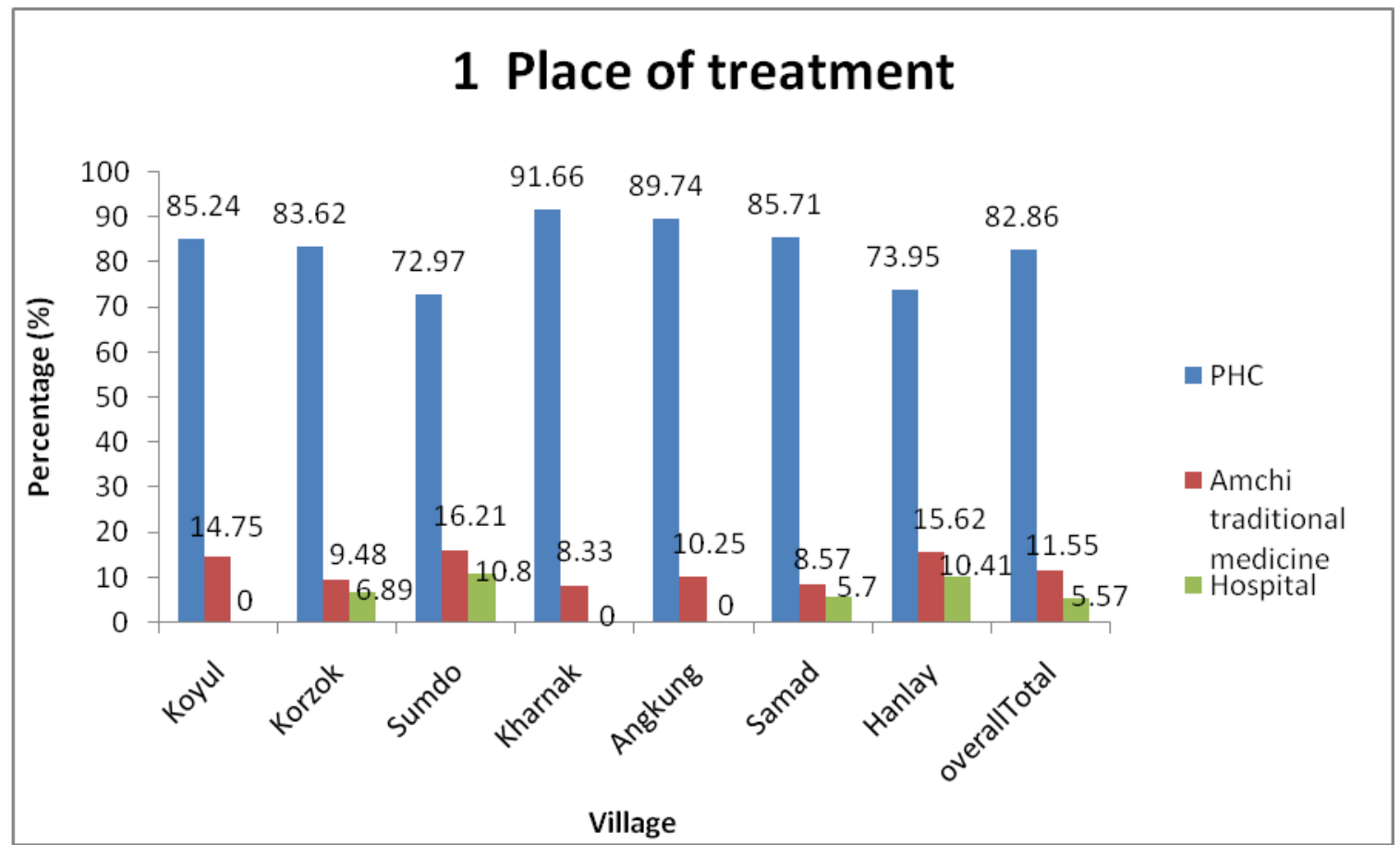

\section{Impact on Health status during migration}

The graph shows that majority i.e. $82.86 \%$ of both women and children from all the above seven villages go to PHC because PHC also keeps moving with their camps so they prefer to go to PHC. Whereas $11.55 \%$ from all villages went to amchi, because amchi do not charge for consultation and treatment but relies on the villagers for their help in pastoral activities and for supply of grains and only $5.57 \%$ of respondents went to district hospital Leh when they are seriously sick. From the above information it was observed that respondents visit doctors according to their feasibility.

Analysis of the table reflects the general health of respondents. Data from the table reveals that $100 \%$ of the respondents from all the villages suffer from general diseases like fever, cold, cough, blood pressure, headache, deficiency diseases, etc. Most of Changpa women were suffering from anemia and children suffer from deficiency of vitamins as
Ladakh is characterized by poor vegetative cover and low plant production especially remote areas like Changthang with the result their diet is deficient in various important nutrients which often leads to anemia \& other deficiency diseases.

The table depicts that majority that is $90.28 \%$ of respondents observed that women's health is important for her because if her health will be good, she will automatically perform all the tasks efficiently and also her household tasks easily.9.71 \% of the respondents noted that women's good health do affect her family because if she will be in good health she can take care of her family members as well her children in a better way.

Table 5 depicts that majority $95.01 \%$ of both women and children from all the villages don't know about balanced diet. Changpa people were suffering from anemia and the reason for anemia remains the lack of awareness about balanced diets and healthy 
lifestyle. Only $4.98 \%$ respondents from above seven villages have heard about balanced diet. Regarding source of information about balanced diet $4.98 \%$ of the respondents get information from radio and ICDS.

It is concluded that $100 \%$ of the changpa nomads were staying in tents (rebos). Most of Changpa women were suffering from anemia and children suffer from deficiency of vitamins as Ladakh is characterized by poor vegetative cover and low plant production especially remote areas like Changthang with the result their diet is deficient in various important nutrients which often leads to anemia \& other deficiency diseases.

\section{References}

Bhasin (2012). Life on an Edge among the Changpas of Changthang, Ladakh, J Biodiversity, 3(2): 85-129.

Dar S A, Javeed K, Mir S H, Dar E A, Yaqoob M, Kundoo A A, Farook U B and Hassan R. 2020a. Response of insect species to fermented sugar and milk baited traps under field conditions. Journal of Entomology and Zoology Studies. 8(6): 562-569.

Dar S A, Mir O, Wani S H, Dar E A, Javeed K, Mir S H, Yaqoob M, Showkat A, Kundoo A A, Hassan R. 2020b. Bioagents (Pathogens, Parasitoid and Predators) of Gypsy moth Lymantria obfuscata Walker (Lepidoptera:
Lymantriidae) and their mechanism of action and Natural mortality. The Pharma Innovation Journal 2020; SP9(11): 23-29

Dar S A, Wani S H, Mir S A, Showkat A, Dolkar T, Dawa T. 2021a. Biopesticides: Mode of Action, Efficacy and Scope in Pest Management. Journal of Advanced Research in Biochemistry and Pharmacology 4 (1), 1-8.

Dar S A, Wani S H, Mir S A, Showkat A, Dolkar T, Dawa T. 2021b. Insect Pest Management in Organic Agriculture A Fast Growing Approach of 21st Century. International Journal of Agriculture, Environment and Sustainability 2 (1), 1-6.

Dar S A, Mir S H, Bashir Z, Javeed K, Sofi M A, Hassan M, Dawa T, Dolkar T, Ashraf S, Rashid S. 2021c. Mode of action of biopesticides (virus, fungi, bacteria, protozoa and nematodes) and their symptoms of infestation to insect pests. Multilogic in Science.10:36, 1498-1505

Rizvi, J. (1996). Ladakh: Crossroads of High Asia. Oxford University Press, New Delhi

Tlak Gajger I and Dar S A. 2021.Plant Allelochemicals as Sources of Insecticides. INSECTS 12 (189), 1-21

www.india etzone.com Tribes of Jammu and Kashmir

\section{How to cite this article:}

Tashi Dolkar, Sabiya Asmat, Anupa Sharma, Feroz Din Sheikh and Hummara Azim. 2021. Women and Children Health Status of Nomadic People of Changthang Ladakh. Int.J.Curr.Microbiol.App.Sci. 10(04): 590-595. doi: https://doi.org/10.20546/ijcmas.2021.1004.059 